\title{
Explaining Quality Management in the Danish and Swedish Public Health Sectors: Unintended Learning and Deliberate Co-Optation
}

\author{
Mattias Örnerheim and Peter Triantafilloub
}

\section{Linköping University Post Print}

\section{Tweet}

N.B.: When citing this work, cite the original article.

This is an electronic version of an article published in:

Mattias Örnerheim and Peter Triantafilloub, Explaining Quality Management in the Danish and Swedish Public Health Sectors: Unintended Learning and Deliberate Co-Optation, 2016, International Journal of Public Administration.

International Journal of Public Administration is available online at informaworldTM:

http://dx.doi.org/10.1080/01900692.2015.1064959

Copyright: Taylor \& Francis (Routledge): SSH Titles

http://www.routledge.com/

Postprint available at: Linköping University Electronic Press

http://urn.kb.se/resolve?urn=urn:nbn:se:liu:diva-128223 


\section{Explaining Quality Management in the Danish and Swedish Public Health Sectors: Unintended Learning and Deliberate Co-Optation}

\section{Mattias Örnerheim \& Peter Triantafillou}

To cite this article: Mattias Örnerheim \& Peter Triantafillou (2016): Explaining Quality Management in the Danish and Swedish Public Health Sectors: Unintended Learning and Deliberate Co-Optation, International Journal of Public Administration, DOI: 10.1080/01900692.2015.1064959

To link to this article: http://dx.doi.org/10.1080/01900692.2015.1064959

Published online: 16 Feb 2016.

Submit your article to this journal $\sqsubset$

Џll Article views: 23

Q View related articles $\square$

View Crossmark data ¿ 


\title{
Explaining Quality Management in the Danish and Swedish Public Health Sectors: Unintended Learning and Deliberate Co-Optation
}

\author{
Mattias Örnerheim ${ }^{a}$ and Peter Triantafillou ${ }^{b}$ \\ aDepartment of Political Science, Linköping University, Linköping, Sweden; bepartment of Society and Globalisation, Roskilde University, \\ Roskilde, Denmark
}

\begin{abstract}
This article examines the development of diverse quality systems in the otherwise quite similar Danish and Swedish public health sectors. After decades of numerous piecemeal medical and managerial quality development programs in both countries, a nationwide mandatory accreditation system was introduced in the Danish health services in 2009. Nationwide quality indicator projects are also found in Sweden, but there has been political attempt to introduce a compulsory system. This article seeks to explain this difference. It argues, first, that resistance from the medical professions blocked the introduction of compulsory, nationwide quality systems in both countries for decades. Second, the implementation of the Danish accreditation system was triggered by a combination of unintended policy learning produced by local reforms in two counties and of the Ministry of Health's carefully orchestrated policy process that served to co-opt critical voices in the medical profession.
\end{abstract}

\section{KEYWORDS}

Historical institutionalism; path dependency; policy learning; quality

management systems

\section{Introduction}

This article examines the different historical developments of the quality systems in the Danish and Swedish public health sectors. Both countries are unitary states that have universal publicly funded health systems in which the political responsibility for running the public hospitals is largely delegated to the second-tier, namely, the counties or regions. As in many other countries, the medical professions in both Denmark and Sweden are powerful and have insisted-for a long time with success-on being in control of quality management. At the same time, both countries have seen pressure from politicians and an emerging group of hospital and quality managers to implement quality assurance measures (Saltman, Vrangbaek, Lehto, \& Winblad, 2012). Finally, the quality management of the health services has changed substantially in both countries over the last two decades in order to pay more attention to user needs and choices.

Notwithstanding these similarities, the quality management of health services in Denmark and Sweden has developed in different directions. After many years characterized by a variety of piecemeal medical and managerial quality development programs, the introduction of a mandatory accreditation system in the Danish health services in 2009 broke with this tradition in at least two ways. First, the new accreditation system, the Danish Quality Model (DDKM) forged a systematic link between the professional and the managerial lines of quality development in Denmark. In Sweden, these two lines of quality development remain separated, although voluntary attempts to align them are ongoing. Second, it implied that nationwide quality standards and indicators were adopted by all relevant medical service producing organizations in Denmark. While nationwide quality indicator projects are also found in Sweden, notably the National Quality Register developed and managed by representatives of the medical profession, political or managerial attempts to ensure that all medical specialities participate remain voluntary and therefore rather uneven.

On this background, our question is, Why, after many years of similar development, did the quality systems in Denmark and Sweden within a relatively short time develop rather differently? This kind of puzzle has been the subject of sustained discussion and studies within historical institutionalism (HI); see below. Apart from better understanding the particular Danish and Swedish cases, we try to contribute to HI theorizing by pointing to the factor of unintended learning. As we explain below, to the extent that learning has been incorporated as a factor of change in HI theory, it is mainly as a conscious act. At the empirical level, we argue that local changes (new quality systems) 
may have the unintended side effect of changing national systems by lowering the political costs of such changes. In the case of Denmark, the introduction and implementation of accreditation at the hospitals in Copenhagen showed not so much that clinical performance can be improved, but that accreditation is workable in administrative terms and that the political protests from the medical profession can be handled. This kind of unanticipated learning was in itself not sufficient to create a policy reform. At least, the Ministry of Health instigated a protracted policy process with the participation of key representatives from the medical professions, which would gradually co-opt their resistance. A similar window of opportunity for policy learning has not-yet-emerged in Sweden and the attempts to merge professional and managerial quality development concern, while comprehensive, remain much more unsystematic and ad hoc. It should be stressed that our aim is to explain the differential developments of the two quality systems, not to assess their effects be that in terms of cost-effectiveness or clinical value. Accordingly, we do not intend to make any value judgments about the two national quality systems.

This article first briefly reviews the key theories that may assist us in explaining the change of quality systems in the public sector. We argue that HI seems the most promising framework. Second, the selection of cases and data is explicated. We then account for the development of quality management in the Danish and Swedish public health sectors. Finally, we compare and discuss the causes underlying the differential development.

\section{Theoretical perspectives on management reforms}

The study of the politics of quality management systems in the health services has been informed by a variety of theoretical perspectives. In order to assist our attempt to understand the differential quality management reforms in Denmark and Sweden, we discuss two overall approaches, one emphasizing rational calculation and learning, and another emphasizing the importance of contingent and unintended processes. Since we have found no literature explaining differential quality management in public health systems, we need to use more general theories. Two options seem especially useful in this case: first theories of rational calculation and learning, such as public interest theory, rational choice, and principal agent theory, and second institutional theories, in particular HI.

\section{Reforms as the outcome of rational calculations and learning}

One group of explanations can be joined together under the heading of rational calculation and learning in that they assume that actors are mainly driven by the more or less rational (enlightened) calculation of the suitability of means to certain ends. We distinguish here between three types of rational theories: self-interest, public interest, and learning. Rational choice theory essentially assumes that actor behavior is guided by the pursuit of self-interest. Exactly, how this pursuit is translated into concrete action depends on the incentive structure surrounding the actor. In the present case, the political incentive structures in Denmark and Sweden differ in what may be important ways. Even if the regions have significant operational responsibility for the hospital services, the overall political responsibility rests with the government in both countries. However, in Denmark this overall political responsibility is with the minister of health alone. In Sweden, the political responsibility is collectively shared in the government. If the argument that public scandals play an important role for triggering quality reforms in the health sector is correct (Kodate, 2010), we would expect that political responsibility in Denmark creates a stronger incentive than in Sweden to pay attention to general public pressure, overcome resistance from the medical profession, and push for national, mandatory quality management schemes. The analysis thus examines the reactions of the Danish minister of health to scandals in the period shortly before the decision to implement a national, mandatory quality system.

Another explanation is based on public interest or stewardship theory, which seeks to explain reforms in terms of actors largely pursuing what they think is the public good. This theory would explain the push for quality management reforms of the public health service in terms of politicians seeking to secure public value for the taxpayers' money and, ultimately, the improvement of public health. While this seems plausible, it does not help us explain the national reform differences. A rational explanation for this difference would presume that the public interest, such as the health status of the two Danish and Swedish populations and/or the key features of the health system differed to the extent that this would call for different public management reforms. As we will show below, this was and is not the case.

The notion that reforms are driven by experiences and policy learning has close affinities to public interest and stewardship theories. Recently, Hemerijck has argued that we may benefit from explaining such incremental changes of welfare policies and schemes in 
terms of the capacity of systems and, not least, policy elites to calibrate institutions through social learning processes (Hemerijck, 2013). While we are sympathetic to this attempt to give more room for historically specific ideas, reflections, and calculations in the design and redesign of public management schemes, we find that Hemerijck's emphasis on the deliberate pursuit on goals based on reflections over past experiences does not seem to leave much analytical space for grasping the unpredictable and unintended dimensions of change. In our view, the literature on planning and policy implementation abundantly supports the claim that the consequences of reforms of public management schemes almost always result in some unplanned or unintended consequences (Pierson, 2000; Pressman \& Wildavsky, 1973).

\section{Reforms as the unintended outcome of historical processes}

While we find the notion of policy learning useful, we need to approach it, not as a rational deliberation around some extra-political societal goals, but as a political and conflicting process leading to a series of diverse, unpredictable, and often more or less contradictory political goals. Such an understanding of policy learning will allow us to provide a more adequate understanding of the kind of policy learning taking place through the development of quality systems in the Danish and Swedish health sectors.

In order to grasp learning as the unintended result of events often dating back in time, we turn to HI. The basic tenet of $\mathrm{HI}$ is that decisions and actions of the past-wittingly or unwittingly-may contribute to the making of particular institutional paths that serve to shape future decisions and actions. Once a path is established it may be very difficult to change the basic course of regulatory actions, even if the proposed change may be more socially optimal, because of the economic costs (North, 1990), political costs (Pierson, 2004, 2011) or both entailed by a change. While HI emphasizes stability, it also offers suggestions for understanding change and the erosion of the efficacy of hitherto followed paths. One type of change may derive from sudden shocks, such as war, natural disasters, or the global financial crisis, which offset existing paths by urgently requesting new solutions. Another type of change follows a longer-term build-up of pressures, such as changing demographic composition, steadily increasing structural financial deficits, or changing citizen preferences that create a "critical juncture" of institutional redesign (Pierson, 2000, 2004). Both these type of changes, however, are largely confined to forces external to the organization or political system in which institutional paths are having effects. In the present case, we do not find shocks or major changes in the external environment.

In order to understand the changes of the Danish and Swedish health quality systems resulting from changes within the public health system, we may turn to Mahoney's and Thelen's argument that long-term incremental change internally in an organization or a political system may ultimately lead to the dissolution of existing tracks and the construction of new ones (Mahoney \& Thelen, 2010). They identify four mechanisms of incremental change: displacement, drift, conversion, and layering. However, in the present case, only the latter mechanism seems relevant and then only partially. In both countries, the introduction of quality management schemes supplemented rather than displaced existing schemes. As in a recent study of health management reforms in The Netherlands (Bovenkamp, De Mul, Quartz, Weggelaar-Jansen, \& Bal, 2013), the mechanism of layering of distinct regulatory approaches can be found both in Denmark and Sweden where older information and quality systems have been supplemented rather than replaced by new ones. However, layering does not really explain the quite comprehensive change taking place in Denmark by which existing institutions were subsumed to a new, overarching scheme.

In sum, HI seems very promising in explaining the difficulty in reforming the quality systems, something observed in both countries. It also convincingly argues that reform change may be due to a mechanism internal to the public health system, such as layering. However, the existing mechanisms of change identified by HI do not fully explain the radical change observed in the Danish case. Instead we argue that unintended learning within the political health system is an important part of the answer in the present case. Policy learning can result, we think, not only from a planned and rational process where learning is a pregiven goal, but also from local programs that unintentionally showed that technical problems and local resistance can be handled in a politically acceptable way. Accordingly, in the following, we try to show how the interests of the medical profession were at least partially modified through a re-articulation of the notion of quality and how it is best managed. Essentially, prominent representatives of the medical profession accepted that the improvement of the quality of health services hinge not only on knowledge and procedures for strictly clinical practices, but also-to some extent-on administrative and organizational procedures and standards. 
The term institution is used here largely in line with March and Olsen's notion of rules, that is, formal and informal codes of conduct (March \& Olsen, 1989). Yet, in order to illuminate the differential developments of the quality systems we focus on the ways in which such rules are articulated in particular regulatory approaches. The latter is analyzed along three dimensions by which the Danish and the Swedish developments seem to differ significantly, namely, professional versus managerial, voluntary versus compulsory, and national versus local rules. The first dimension seeks to highlight whether the rule is mainly developed and used for professional (medical) purposes or mainly for managerial ones, the second whether the rule is legally mandatory or not, and the third whether the rule is (supposed to be) nationally uniform or local only. It should be stressed that the two values of the three dimensions be regarded not as clear-cut dichotomies but rather as extreme positions along a continuum. With regard to the first dimension, it is particularly important to note that many of the rules that began as professional quality tools were at some point employed for managerial control purposes. We also find the reverse movement by which regulatory instruments developed for managerial purposes are-to some extent at least-adopted by professions to improve clinical practices. Notwithstanding this crossing over of purposes, we think it makes sense to uphold the distinction between professional and managerial quality systems, because the Danish and Swedish cases differ fundamentally in the ways in which such crossings have taken place. Finally, it should be noted that these three analytical dimensions were not theoretically deduced, but were gradually developed as we went through the data material (see below).

\section{Method}

This study adopts a most similar systems design in order to better isolate and understand the differential institutional forces shaping of quality management in health service systems. The Danish and Swedish health systems are remarkably similar in terms of the public governing of the consumption, provision, and production of health services (cf. Burau \& Blank, 2006; Moran, 2000).

The health-care systems of both Denmark and Sweden are organized and managed on three levels, namely, national, regional/county, and local/municipal. At the national level, the Ministry of Health in Denmark and The Ministry of Health and Social Affairs in Sweden establish principles and guidelines for care and set the political agenda for health and medical care. The ministries, along with other government bodies, supervise activities at the lower levels, allocate grants, and periodically evaluate services to ensure correspondence to national goals. A potentially important difference here is that in the Danish system, the minister alone is responsible for political outcomes, whereas in Sweden responsibility is shared by the government. In case of public exposure of problems in the health sector, the individualized responsibility may provide the Danish minister of health with a stronger incentive to act to deal with such problems compared to her Swedish counterpart. In both countries, responsibility for financing and providing health care is decentralized to the county councils that are elected by the public every 4 years. The executive board or hospital board of a county council exercises authority over hospital structure and management, and must ensure efficient health-care delivery. County councils also regulate prices and quality of service offered by private providers. Private providers are required to enter into a contract with the county councils. At the local level, municipalities are responsible for maintaining the immediate environment of citizens such as water supply and social welfare services. Both countries have recently seen a tendency of increasing municipal responsibility for follow-up care for the patients treated at hospitals, the disabled and elderly, and long-term care for psychiatric patients.

Denmark and Sweden are also quite similar with regard to the diffusion and employment of New Public Management (NPM) reforms (Kuhlmann \& Jäkel, 2013; Pollitt \& Bouckaert, 2011). This is relevant as the differential use of quality management in the health sector could be seen as the reflection of a more general difference in the Danish and Swedish position on NPM.

The data supporting the present study derive from a variety of documents, such as laws, regulations, policy papers, evaluation reports, medical journals, newspaper articles, and existing social science studies on quality management in the health services of Denmark and Sweden. The documents were analyzed with a view to map all national and regional quality systems in the public health sector from the mid-1980s to 2013. After a first read and inter-state comparison of the reforms, we found that the quality systems differed and gradually changed significantly along the three analytical dimensions mentioned above, that is, professional/ managerial, voluntary/compulsory, and central/local rules. By professional quality systems, we are referring to those systems that are primarily attuned to secure and enhance the clinical quality of the medical services and the design of which are primarily controlled by the 
medical profession. By managerial quality systems, we are referring to systems that are primarily attuned to instill organizational setup and administrative procedures that allow politicians and top managers (in the Ministry of Health and the hospitals) to govern the conduct of professionals in ways that politicians and top managers-but not necessarily professionalsbelieve will improve the quality of the health services. By compulsory quality systems, we refer to all initiatives that are legally binding or the outcome of an administrative settlement decided by the central government. Everything else is regarded as voluntary. By central systems and rules, we are referring to those issued by the central state government. All others are regarded as local. As these dimensions seemed to be important to grasp the differential development in Denmark and Sweden, we went over the quality systems again and mapped them systematically according to the three dimensions.

In Denmark, document research was based above all, but not exclusively, on three sources. First, we scanned Infomedia, which is an electronic database containing articles from all Danish newspapers, most journals, and government newsletters since 1986, and second, the homepages of the Ministry of Health, the Board of Health, and Danish Regions, which contain all key policy documents. Third, we undertook a Google search by using the Danish terms for quality, management, health, and hospitals. The tracing of Swedish documents began by scanning the homepages of the Swedish Government, the National Board of Health and Welfare (NBHW), the Swedish Association of Local Authorities and Regions (SALAR), Swedish Council on Health Technology Assessment (SBU), and the homepage of Quality Registers (QR). In the second step, we searched Google using the Swedish terms for quality, management, health, and quality registers. The reference lists of all documents in Sweden and Denmark identified were scanned for other relevant documents. This procedure was reiterated until no new and relevant documents were identified.

\section{Sweden: Voluntary connection of managerial and professional quality systems on an ad-hoc basis}

The development of Sweden's health quality system can be separated into two distinct systems, a managerial and a professional one. This section will outline the main development of these two systems and the attempts to link them in order to understand why the linkages remained ad hoc and voluntary.
Professional and managerial quality management measures in Swedish health care

Quality assurance discussions were initiated by the Swedish Institute for Health Services Development (SIHSD) already in the 1970s. Several methods were proposed to measure quality of processes and structures to control costs and to address problems as long waiting times, shortcomings in service, and low productivity (Erlingsdóttir, 1999; Garpenby, 1997; Ovretveit, 1994). However, these proposals were only implemented in very limited ways if at all.

It was only when The Federation of County Council $(\text { FCC })^{1}$ and Institute for Health Care Improvement (IHI) started collaborating in the 1990s that the process got under way again. They launched a variety of Total Quality Management (TQM) programs, models, and techniques in order to improve and assure the quality of health-care service (Bejerot \& Erlingsdóttir, 2002). This transformation process was trigged by several factors. At the general level, difficulties with controlling increasing health-care expenditures, long waiting times for access to health services, and widespread patient dissatisfaction (ESO, 1985; Garpenby, 1992; Larsson, Letell, \& Thörn, 2012) seem important. More specifically, the publication of the NBHW's regulations of management systems and systematic quality work (SOSFS, 1993) and the 1997 revision of the Health and Medical Services Act (1982) both forced health-care organizations to launch quality assurance programs, though the specific design of these was largely up to the individual organizations (SOSFS, 2011).

In the following, we account for the most comprehensive and persistent quality management measures implemented in the Swedish health-care sector since the 1990, namely, the quality development tool "QUL," National Patient Survey, the Breakthrough Series, and not least the Quality Registers. The "QUL" tool (in English: Quality, Development, Leadership), which was introduced by FCC in 1996, is one of the most widespread management quality instruments in Swedish health care (Bejerot \& Erlingsdottir, 2002). The QUL aims to make health-care organizations aware of their routines and how to guarantee quality and customer services. The clinic or hospital describes and evaluates the activities in the areas of management, information, planning, coworkers, processes, results, and consumer satisfaction. The purpose is to reveal malfunctions from a customer point of view. The final step is to implement improvement of health-care services and processes based on the knowledge from the description and the evaluation.

The "Breakthrough Series" (BS), originally developed by the IHI, was introduced in Sweden in 1996. It is a collaborative method seeking to improve health 
services delivered by clinics or primary care centers. Teams of medical staff work together on a focused topic area to improve clinical quality and to contain costs (IHI, 2003). Local experiments and small-scale tests play an important role for improving actual practice (Edström, Svensson, \& Olsson, 2005). The FCC, and later SALAR, have been proactive, and also quite successful, in convincing clinics and primary care centers to use the breakthrough method. Today, at least one team has been participating in a breakthrough project in all Swedish counties.

In 2009, the first National Patient Survey (NPS) was carried out in primary care. NPS is a generic name for periodic surveys of patient experienced quality in health care. The NPS is now coordinated by SALAR and surveys are now conducted every second year in primary care and every second year in specialized hospital health-care (NPE, 2014). The number of county councils participating in the NP has been steadily increasing since 2009. By systematically measuring and comparing patients' conceptions of health care (NPE, 2014), the NPS allows both health-care managers and patients to identify the relative merits of their particular health organization. While received positively by the public and health-care managers, the medical profession has been quite skeptical of the information value of the NPS.

Whereas the three quality programs described above all have been initiated by health-care managers, the Quality Registers (QR) are mainly the product of the medical profession. The health registers were initiated in the 1970s. These registers, which contained information about diagnosis, interventions, and results of individual patients, aimed to enable medical practitioners to systematically follow patients' treatment over time and ultimately to provide them with the best possible clinical care in a specific medical area. The funding of the registers came primarily from individual research funds. This was partially to change in the 1990s when the public administrators at SALAR saw the registers as a possible tool to improve the quality of the health-care sector in a more comprehensive and systematic fashion (Bohlin, 2011; Garpenby, 1997). The registers would now receive stable government support, which allowed the number of quality registers to increase and cover more medical disciplines. Moreover, the introduction of new computer technology in the early 2000s enabled the quality registers to process greater quantities of information and start publishing medical results as benchmarking (Blomgren \& Sahlin, 2007; Blomgren, 2007).

Especially during the early 2000s, there was a debate on the exposure of governmental control efforts regarding the QR and the professionals' resistance (Bejerot \& Hasselbladh, 2011). In order to obtain financial support, the registers are being put through an annual review process by the Decision Body for National Quality Registers (DBNQR). ${ }^{2}$ It could be argued that the self-scrutiny and self-improvement of the QR is a more pervasive and effective form of government control than centrally imposed systems. However, since the government is highly dependent on the medical expertise in developing this quality system, this could also be interpreted as governmental efforts to cater to the medical profession's demands for medical quality, rather than oppose the medical profession. Or it could be read as a governmental expression of powerless governance or playing symbolic politics. The interest in management reforms and individual profit amongst the medical profession should also not be underestimated (Hall, 2012). Notwithstanding the financial and technological changes, the medical profession have remained in control of the individual registers' content and management driven by legitimizing and development of professional work (Levay \& Waks, 2009). This view is also backed up by DBNQR 's deliberate principle that the registers primarily are the medical professions' tool for learning and improvement and that proposals about financial supervision based upon the registers should be treated with caution (NQR, 2015; SALAR, 2010).

In sum, a number of quality management models developed on an ad-hoc basis within two distinct and largely unconnected institutional tracks. On the one hand, the managerial quality programs all seek, though in different ways, to spur voluntary quality improvements through new information systems and procedural (or process) changes. QUL is used to encourage competitiveness to encourage quality work, the BS is a way of implementing quality improvements in practice, and NPS provides information about patient satisfaction. On the other hand, the national quality registers are essentially the doctors' (and to lesser extent the nurses') instrument to systematically monitor and improve the clinical quality of their work. Unlike the managerial quality programs, the registers seek to improve quality not by focusing on procedures and processes, but by producing and using individualized clinical knowledge about the relationship between clinical interventions on the one hand and clinical results for the individual patient.

National politicians and administrators have tried to forge a homogeneous policy by changing regulative institutions. Moreover, along both tracks, we find NPM inspired ideas about focusing on the patients and their right to information and choice have gained 
influence. Nevertheless, the implementation of quality management mechanisms have remained remarkably uneven and uncoordinated (Garpenby, 1997; Nilsen, 2010). In particular, the county councils and not least the medical profession have insisted on maintaining, developing, and managing their own quality systems. This has, in turn, led to significantly different solutions and to the development of two largely unconnected quality management tracks.

\section{Soft policy as a way of combining managerial and professional measures}

The central Swedish health authorities acknowledge the need for the knowledge produced in both the managerial and the professional track in order to improve health care at a national level. However, rather than trying to curb the autonomy of the county councils and the medical profession by forcing them to adopt specific quality programs or models, two coordinating instruments have been introduced, namely, the National Guidelines (NG) and Open Comparisons (OC), both aiming to overcome the difficulties in translating professional knowledge into management methods.

Since 1996, the NBHW has produced guidelines directed at the health-care profession. Physicians criticized the early versions of the guidelines but a significant room for discretion at the local hospitals has gradually made doctors accept the system. After 2008, the guidelines functioned as a basis for decision-making for public officials and politicians in prioritizing treatment methods (NBHW, 2014).

In the beginning of the 2000s, SALAR and the NBHW agreed on establishing OC in health care. The purpose of OC, which went into operation in 2006, is to create transparency and eventually learning in the public health services (Lindgren, Ottosson, \& Salas, 2012). Information is extracted from existing systems, notably the NPS, QR, and the Health Data Register. Currently, the OC contains 162 indicators in a number of areas such as specific diseases, costs, accessibility, and patient experiences (Öppna jämförelser, 2014). The rationale is that regular standardized comparisons of these areas, rather than legal sanctions, will spur the sharing of best practices (Blomgren \& Waks, 2010). So far there is no documentation of such learning effects concerning the OC. However, individual QRs have been quite active in showing learning effects of quality improvement at the clinical level (Elg, Stenberg, Kammerlind, Tullberg, \& Olsson, 2011; Peterson et al., 2007). Despite the fact that information generated in the $\mathrm{QR}$ is used in a political way in the OC, the registers have retained their basic function of being a patient-focused system for monitoring treatment results linked to individual diagnosis and medical results. Accordingly, the purpose and meaning of QR is not dependent upon the OC (Örnerheim \& Wihlborg, 2014).

These two national initiatives, the OC and NG, have gradually made some headway into the professional quality management track. Both seek to better integrate existing knowledge and systems trying to ensure the quality of health services. Yet, neither of these amounts to a mandatory, national program for managing the quality at hospitals and other health-care organizations. So far, Swedish health authorities have focused on ensuring the medical professions' more or less voluntarily participation. It seems that the public health authorities have found it more politically expedient to accommodate the medical professions' demands, instead of forcing them into a specific program. The medical profession seems to accept the steering in the two above-mentioned cases as long as they have control of the content, get financial support, and exert some influence on the steering (Garpenby, 1999; Levay \& Waks, 2009).

Thus, while numerous and quite comprehensive measures have been taken to develop and consolidate quality management of the Swedish health services, these measures remain rather ad hoc, fragmented, and above all based on voluntary instruments to overcome normative and cognitive differences in managerial and professional quality assurance.

\section{Denmark: Unexpected policy learning and merging of professional and managerial quality systems}

As in Sweden, quality assurance in the health sector in Denmark has largely developed along two separate tracks. First, the medical profession has developed a variety of mainly clinically oriented quality schemes and techniques since the 1970s. While they have been supported by the public health authorities, these efforts have been more or less fully controlled by the medical profession. Second, public health authorities (politicians and top managers) have, since the early 1990s, embarked on a series of strategies and programs to integrate existing quality schemes into a nationwide strategy. Until recently, these managerial interventions remained voluntary and largely disconnected from existing professional schemes. The launching of the mandatory accreditation system aimed above all to remedy the shortcomings, rather than replace, earlier quality measures. 


\section{Insufficient public health quality management measures: Professional and managerial}

The first step by the Danish health authorities to develop a national quality management strategy was taken in 1993 (Sundhedsstyrelsen, 1993). The strategy, which was developed in cooperation with WHO/ EURO, asserted that "quality development" would be a central tenet of future planning of the Danish health services. Quality development was to be based on both self-control, that is, the participation of the medical professions, and on user viewpoints, that is, the satisfaction of the users of medical services. Finally, it proposed a national quality evaluation model, such as ISO 9000. It is important not to exaggerate the influence of this strategy. First of all, the strategy came neither with any legal or regulatory reforms nor with any attempts to systematically monitor developments (at a national level). Moreover, the idea of a national quality evaluation model was vehemently rejected by the medical professions, which found that the medical benefits of, for example, ISO 9000 dubious (Rådet for Medicinsk Kvalitetssikring, 1993).

Informed by the political attention generated around the National Strategy of the Quality of the Health Services, the medical profession launched the so-called clinical databases, which were gradually but systematically developed during the 1990s and 2000s (Sundhedsstyrelsen, 2000). Based on a series of indicators, which are regularly updated, the databases seek to examine the correlation between particular forms of treatment on the one hand and patient cure on the other. The number of databases has gradually been expanded to include around 60 diseases (Databasernes Fællessekretariat, 2012). Notwithstanding this apparent success, it has been difficult to make all parts of the health services systematically use the knowledge generated in the databases.

The former counties and a wide range of medical associations agreed in the late 1990s to establish the National Indicator Project (NIP) in order to develop and implement standards and indicators for the assessment of the quality of key health service deliveries. The NIP focuses on the documentation and quality development a series of practices diagnosing and treating specific diseases. The indicators developed were originally intended to be used both by the medical organizations and by patients and other citizens to gain insights into the quality of medical services. However, this last ambition was never really met as it turned out to be quite difficult to translate medical indicators into something useful for the patients. Accordingly, the NIP was closed down in 2012, though the activities focusing on the documentation of medical services for internal use by the hospitals was continued in the new Regional Clinical Development Program (Databasernes Fællessekretariat, 2012).

From the early 1990s, an increasing number of Danish hospitals started to experiment with user satisfaction surveys. In the absence of state regulation or even guidelines for such surveys, the scope and regularity of these surveys varied significantly. While hospitals managements tended to see these surveys as a useful indicator of the quality of hospital services, the medical staff was generally not convinced of their utility. It was only in 2000 that the Danish government agreed with the counties to introduce standardized, national patient satisfaction surveys (Det nationale råd for kvalitetsudvikling i sundhedsvæsenet, 2001, del A). The aim of the surveys, which are conducted every second year at all Danish hospital departments, is to identify and compare differences and changes in quality levels across hospitals and to enable patients to make an enlightened choice of hospital services.

In sum, until the mid-2000s, the Danish health sector saw the development of a series of quality management programs along two distinct institutional tracks: Professional and managerial quality development programs. Attempts were made to bridge these two tracks, but, as in Sweden, they did not really succeed. Accordingly, there was no guarantee that the quality of knowledge generated by professionals was actually used in shaping the health services provided by hospitals, general practitioners, and other providers.

\section{Accreditation: Mandatory linking of the professional and managerial tracks}

In 2009, the DDKM was implemented as all Danish hospitals. The backbone of the DDKM is its standards and indictors. The current, second, version of the model contains a total of 82 standards of which 39 are organizational ones, 40 general patient process standards (including include reception, assessment, diagnosis, invasive treatment, medication and observation), and three specific sickness standards (Institut for Kvalitet og Akkreditering i Sundhedsvæsenet, 2012). Another fundamental feature of the DDKM is that it urges, actually forces, medical staff to develop, use and monitor their own specific guidelines for dealing with the patient processes and the specific sickness standards. A recent study including 20 interviews with the medical staff of two Danish hospitals suggested that they have substantial influence on these guidelines that structure their everyday work with patients (Ekdahl \& Ottesen, 2015). With regard to the patient process and sickness standards, in brief, the standards 
and indicators espoused by DDKM reflect both managerial and professional concerns.

The implementation of DDKM was preceded by a long and tedious political process that according to analytical flavor may be dated back several decades (Author reference). As in Sweden, the Danish media regularly published hospital "scandals" throughout the 1990s, that is, obvious and systematic medical malpractice such as erroneous hip surgery cases and poor cancer treatment. By the end of the 1990s, the Minister of Health seemed to have had enough of negative media stories. Thus, in 2001, the Minister entered an agreement with all Danish counties to initiate the development of a compulsory national model of hospital accreditation (Amtsrådsforeningen, 2001).

While the explicit aim of this model was to have a national system improving the quality of hospital services and reducing the medical malpractice, it was not clear at the time what such a system should look like. Yet, over the next few years, the Ministry of Health would increasingly point to accreditation as a viable model. While it is difficult to identify any direct causal linkage, it is hardly a mere coincidence that two counties were actively propagating accreditation as a possible national quality system integrating both managerial and professional purposes. In early 2000, the Capital's Hospital Association had decided to introduce the US Joint Commission accreditation system to all public hospitals in Copenhagen (HS: Ja til kvalitetscheck på sygehusene, 2000). During a visit to Chicago in July 1999 organized by the Joint Commission, the directors of the Capital's Hospital Association had received a very positive impression of the JC accreditation model (Bagger, 2012) and by 2002, the model was implemented under great media attention in all the hospitals of the Copenhagen metropolitan area. Meanwhile, the County of Southern Jutland had been convinced in 2001 by the British quality organization Health Quality Service that their accreditation model was superior (Sønderjydske patienter får bedre kvalitet og sammenhæng, 2001). Accordingly, this model was partially implemented in 2003 in most but not all hospitals of Southern Jutland (Antonsen, Rasmussen, \& Friis, 2006; Det Centrale Kvalitets- og Informatikudvalg for almen praksis, 2005). While many doctors at the hospitals in Copenhagen remained critical of accreditation (Right \& Kjerulf, 2002, 2005), the hospital managements of both counties remained positive. They argued that accreditation allowed the hospitals to systematize and, not least, document the many quality development efforts taking place (So ein Ding müssen wir auch haben, 1999; Sønderjydske patienter får bedre kvalitet og sammenhæng, 2001). Documentation was important not only to ward off criticism from politicians and the public, but also to allow learning. Accordingly, the implementation of the accreditation models may not have brought about any change in clinical practice at all as the immediate requirement simply is that doctors document the clinical practices they (already) undertake. In particular, the hospital directors in the Capital's Hospital Association went at great length to defend the JC model which they had implemented by trying to make that model the national standard (Bagger, 2012).

The fact that two accreditation models were actually implemented seems to have been instrumental to the making of the DDKM in at least two ways. On the one hand, the experiences from Copenhagen and Southern Jutland showed that it was actually possible to implement and operate a quality management model that merged managerial and professional concerns. True, a number of hospital doctors remained critical of accreditation which they found too bureaucratic. Yet, both the Copenhagen and the Southern Jutland cases seemed to show to national politicians, notably the Minister of Health, that such resistance was manageable and was outweighed by the benefits of being able to document that quality management practices are actually conducted in a systematic manner. In turn, the national representatives of the medical associations seemed to decide somewhere along the process that the most viable strategy was to seek to cooperate with a view to influence the actual design of the model, rather than outright rejecting accreditation (Jacobsen \& Poulsen, 2004; Krøll \& Mainz, 2007).

On the other hand, the existence of two competing accreditation models made it difficult to decide on one of these two as any decision in favor of one model would be met with criticism by the other county. This situation combined with a widespread skepticism in the medical profession toward accreditation made the Ministry of Interior and Health announce that the model should be attuned to the Danish context (Indenrigsog Sundhedsministeriet, Amtsrådsforeningen, \& Hovedstadens Sygehusfællesskab, 2003). Rather than adopting one of the existing models, the development of a Danish model would entail a process of consultation with virtually all parts of the medical profession. Couched in terms of Danish tradition of policy dialogue, the Ministry no doubt hoped that this consultative process would convince the majority of hospital doctors to support accreditation. The immediate result, however, of inviting in all the medical associations was that the process became engulfed in protracted disputes within and between the many groups working on defining the scope and standards constituting the model. The Institute of Accreditation and Quality in Health Care (IKAS) was 
established in 2005 in order to reinvigorate the process of developing the DDKM. Representatives from the medical profession were richly represented in the thematic groups elected by IKAS with the crucial task of formulating suitable standards for the model. Even with this renewed momentum, the process dragged on as two versions of the models with all their hundreds of standards went through hearings and pilot tests. The model was finally introduced at all Danish hospitals in August 2009.

\section{Discussion and conclusion}

In this article, we have tried to show how quality systems in Denmark and Sweden after decades of rather similar historical trajectories recently developed rather differently. In both countries, we observe an intensification of the development of quality assurance systems along two more or less separate paths: a professional (medical) and a managerial (political) one. Through a number of voluntary regulatory approaches, attempts were made by health authorities in both countries to bridge these paths. The general ambition of most of these voluntary instruments was to try to generalize the best local practices into national guidelines or standards to be adopted by all hospital and other health organizations. The similarities and differences of these attempts are synthetized in Table 1.

Table 1 tries to summarize the main characteristics of the development of the health-care quality systems in Denmark and Sweden. The column "Disjointed quality assurance" denotes schemes in which managerial and professional rules were largely operating separately, that is, with low levels of coordination and/or integration. The column "Coordinated quality assurance" in contrast denotes quality schemes in which managerial and professional purposes are more or less systematically coordinated and integrated. Throughout the 1980s, quality assurance in both Denmark and Sweden remained largely disjointed and based on voluntary efforts by various parts of the medical profession. Under the influence of NPM ideas in general and total quality management schemes in particular, a number of new quality systems were pushed by public health authorities in both countries during the 1990s. The medical profession was now no longer the driver of quality reforms, though they remained influential in their design and in particular in their implementation. From around the turn of the millennium comprehensive efforts were made in both countries to coordinate and integrate the clinical systems controlled by the medical professions and the managerial systems controlled by politicians and health-care managers. In Sweden this effort has been conducted by voluntary means only. In contrast, what started as local voluntary experiments with hospital accreditation in Denmark ultimately ended up-after a lengthy political process of consultation and co-optation-as a national mandatory system.

The difficulties in both countries with significantly altering the quality systems and aligning the professional and managerial regulatory approaches may be explained by the political costs. Thus, in both countries attempts to establish mandatory nationwide schemes were strongly resisted by the medical professions. Forcing them to integrate the mainly clinically oriented quality schemes with nationwide managerial process-oriented schemes was and is associated with substantial political costs and practical problems. Thus, it seems fair to assert-in line with HI theory-that the existence of two parallel quality management paths which for a long time worked to fend off radical reforms.

To understand why (national and regional) politicians in Denmark insisted and eventually managed to implement a national, compulsory quality system and Sweden did not, we turned first to rational choice theory. We argued that the circumstances guiding the choices of Danish and Swedish health politicians, respectively, differed with regard to least one point, namely, Ministerial responsibility. We assumed that individual responsibility contributed to making the Danish Ministry of Health push relatively-to Sweden-hard for a national quality management reform. Our analysis suggests that prior to the decision in 2001 to develop a national, mandatory accreditation model, the Danish Minister of Health had for a long time been under public pressure to push for a reform that at least would appear to respond comprehensively and decisively to the many reports of medical malpractice at the hospitals.

Table 1. Major quality assurance schemes in the Danish and Swedish health sectors.

\begin{tabular}{lll}
\hline & \multicolumn{1}{c}{ Disjointed quality assurance } & \multicolumn{1}{c}{ Coordinated quality assurance } \\
\hline Voluntary & DK and SW 1980s and 1990s: & DK 2000-2009: Local accreditation schemes \\
Local & Register studies, clinical guidelines, quality circles, user surveys, etc. & SW 2000s: Various integrated management instruments (OC, NG) \\
National & DK 1990s: Clinical databases, national indicator project & \\
Mandatory National & SW 1990s and 2000s: QUL, BS, NPS & DK 2009-14: Implementation of DDKM \\
\hline
\end{tabular}


Thus individualized ministerial responsibility in the Danish case seems to have contributed to making the Minister push for a quality management reforms even if he was well aware that it would be met with intense resistance from the medical profession.

While the rational pursuit of ministerial interest may provide part of the explanation of the different historical developments in the two countries, we find that at least one other and probably more important event was at play in the Danish case, namely, unintended policy learning. That is, policy learning which is useful not as a rational deliberation around some extrapolitical societal goals, but as a political and conflicting process leading to a series of diverse, unpredictable, and often more or less contradictory political goals. In the Danish case, policy learning resulted less from a planned and rational process where learning is a pregiven goal, but more from local programs that unintentionally showed that technical problems and professional resistance can be handled in a politically acceptable way. In particular, the adoption of an accreditation model that essentially entails that it is the medical staff itself that formulates the guidelines structuring their everyday work seems to have contributed importantly to reduce local resistance.

Sweden have had no obvious window of opportunity since there were no mechanisms, such as prior learning of a local comprehensive system, that the key professional and national political actors could refer to and ultimately spur an agreement on a national mandatory system. Sweden has, rather, been deliberately cautious and chosen another route, namely, a revision of national health authorities (Ds, 2014). The strategy is to gather information from different quality systems to support a public knowledge management, which in short includes refinement of the responsibility of national health authorities for these matters and collaboration between the concerned authorities. The extent to which this documentation and cooperation amongst national health authorities are effective or mere castles in the air is open to doubt, and should be left for further examination.

We think that unintended policy learning fits well within the larger theoretical edifice of $\mathrm{HI}$ and its attempt to explain change. We saw that until recently HI has been very focused on how forces outside the political-administrative system have contributed to change. More recently, more focus has been attributed to internal factors, though these have mainly been employed to understand incremental change.

Finally, we have argued that resistance against the implementation of the model was reduced through deliberate co-optation of the medical professions through their systematic participation in the development of a national model. In Sweden, changes of the quality systems have only been incremental despite widespread concerns over the inability of the existing measures to deal satisfactory with quality problems. In particular, the health quality systems have seen quite extensive layering in which public management ideas and logics have to some extent encroached on the professional area via the back door. In terms of future research, we would like to point to the need for systematic evaluations of the two national quality systems, in terms of their clinical, economic, and motivational effects. Such evaluations, which are currently very scarce, would enable enlightened normative discussions of the pros and cons of quality management systems in the health sector.

\section{Notes}

1. Predecessor to Swedish Association of Local Authorities and Regions (SALAR).

2. The Decision Body for National Quality Registers was at the time made up of representatives from SALAR, NBHW, and also the medical profession and Register-Holders.

\section{References}

Amtsrådsforeningen. (2001). Aftale om amternes økonomi for 2002 mellem regeringen og amtsrådsforeningen. København, Denmark: Finansministeriet.

Antonsen, K., Rasmussen, H., \& Friis, J. (2006) Akkreditering $i$ H:S. Oversattelser og stabilisering (Master Thesis). Copenhagen Business School, Copenhagen, Denmark.

Bagger, D. (2012). Interview with head of accreditation in the capital region. 24th September. Bispebjerg Hospital.

Bejerot, E., \& Erlingsdóttir, G. (2002). Kvalitetsidéns materialisering i hälso- och sjukvården. In E. Bejerot, \& H. Hasselbladh (Eds.), Kvalitet utan gränser: En kritisk belysning av kvalitetsstyrning (1. uppl.). Lund, Sweden: Academia Adacta.

Bejerot, E., \& Hasselbladh, H. (Eds.). (2002). Kvalitet utan gränser: En kritisk belysning av kvalitetsstyrning (1. uppl.). Lund, Sweden: Academia Adacta.

Bejerot, E., \& Hasselbladh, H. (2011). Professional autonomy and pastoral power: The transformation of quality registries in Swedish healthcare. Public Administration, 89 (4), 1604-1621. doi:10.1111/j.1467-9299.2011.01945.x

Blomgren, M. (2007). The drive for transparency: Organizational field transformations in Swedish health care. Public Administration, 85 (1), 67-82. doi:10.1111/ padm.2007.85.issue-1

Blomgren, M., \& Sahlin, K. (2007). Quests for transparency: Signs of a new institutional Era in the health care field. In T. Christensen, \& P. Lægreid (Eds.), Transcending new public management: The transformation of public sector reforms (pp. 155-178). Burlington, UK: Ashgate.

Blomgren, M., \& Waks, C. (2010). Ett nytt tänk: öppna jämförelser $i$ hälso- och sjukvårdens ledning, styrning och kvalitetsarbete. Stockholm, Sweden: Sveriges kommuner och landsting. 
Bohlin, I. (2011). Evidensbaserat beslutsfattande. In I. Bohlin, \& M. Sager (Eds.), Evidensens många ansikten: Evidensbaserad praktik $i$ praktiken (pp. 31-68). Lund, Sweden: Arkiv.

Bovenkamp, H. M., De Mul, M., Quartz, J. G. U., WeggelaarJansen, A. N. J. W. M., \& Bal, R. (2013, October). Institutional layering in governing health care quality. Public Administration. doi:10.1111/padm.12052

Burau, V., \& Blank, R. H. (2006). Comparing health policy: An assessment of typologies of health systems. Journal of Comparative Policy Analysis: Research and Practice, 8 (1), 63-76. doi:10.1080/13876980500513558

Databasernes Fællessekretariat. (2012). Regionernes kliniske kvalitetsudviklingsprogram. Rammebeskrivelse for anvendelsen af kvalitetsdata fra de landsdoekkende kliniske kvalitetsdatabaser. Version 1.1. Aarhus, Denmark: Kompetencecenter Vest. 20th February.

Det Centrale Kvalitets- og Informatikudvalg for almen praksis. (2005). Det almenmedicinske kvalitetsprojekt. afsluttende rapport, del 2. praksis- og kvalitetsdeklarationer. Det Centrale Kvalitets- og Informatikudvalg for almen praksis, Århus, Denmark.

Det nationale råd for kvalitetsudvikling i sundhedsvæsenet. (2001). Kvalitetsvurdering $i$ sundhedsvoesenet. del A og del $B$. København, Denmark: Sundhedsstyrelsen.

Ds. (2014). En samlad kunskapsstyrning för hälso- och sjukvård och socialtjänst [A coherent knowledge management in healthcare and social care - official government report]. Stockholm, Sweden: Fritze Stockholm.

Edström, A., Svensson, C., \& Olsson, J. (2005). Att mäta för att veta: Praktiska råd och tips om mätning och uppföljning $i$ samband med utvecklings- och förbättringsarbete $i$ hälsooch sjukvården. Stockholm, Sweden: Sveriges kommuner och landsting.

Ekdahl, M. F., \& Ottesen, M. S. S. (2015) Fra akkrediteringsstandard til retningslinje på to udvalgte sygehuse (MA project). Department of Society and Globalisation, Roskilde University, Roskilde, Sweden.

Elg, M., Stenberg, J., Kammerlind, P., Tullberg, S., \& Olsson, J. (2011). Swedish healthcare management practices and quality improvement work: Development trends. International Journal of Healthcare Quality Assurance, 24, 101-123. doi:10.1108/09526861111105077

Erlingsdóttir, G. (1999). Förförande idéer: kvalitetssäkring $i$ hälso- och sjukvården (Diss). Univ. Lund, Lund, Sweden.

ESO. (1985). Produktions-, kostnads- och produktivitetsutveckling inom offentligt bedriven hälso- och sjukvård 1960-1980. Rapport från Expertgruppen för studier i offentlig ekonomi, Sweden.

Garpenby, P. (1992). The transformation of the Swedish health care system or the hasty rejection of the rational planning model. Journal of European Social Policy, 2 (1), 17-31. doi:10.1177/095892879200200102

Garpenby, P. (1997). Implementing quality programmes in three Swedish county councils: The views of politicians, managers and doctors. Health Policy, 39 (3), 195-206. doi:10.1016/S0168-8510(96)00880-9

Garpenby, P. (1999). Resource dependency, doctors and the state: Quality control in Sweden. Social Science \& Medicine, 49, 405-424. doi:10.1016/S0277-9536(99)00130-6
Hall, P. (2012). Managementbyråkrati: Organisationspolitisk makt $i$ svensk offentlig förvaltning. Malmö, Sweden: Liber. 1. uppl.

Health and Medical Services Act. (1982). Sweden. 763. Swedish Government.

Hemerijck, A. (2013). Changing welfare states. Oxford, UK: Oxford University Press.

HS: Ja til kvalitetscheck på sygehusene. (2000). Politiken. 3 February.

IHI. (2003). The breakthrough series: IHI's collaborative model for achieving breakthrough improvement (IHI innovation series white paper). Boston, MA: Institute for Healthcare Improvement.

Indenrigs- og Sundhedsministeriet, Amtsrådsforeningen, \& Hovedstadens Sygehusfællesskab. (2003). Policynotat om den danske kvalitetsmodel for sundhedsvosenet. København, Denmark: Indenrigs- og Sundhedsministeriet.

Institut for Kvalitet og Akkreditering i Sundhedsvæsenet. (2012). Akkrediteringsstandarder for sygehuse. 2. Version. Aarhus, Denmark: IKAS.

Jacobsen, I. A., \& Poulsen, J. (2004). Giv Den Danske Kvalitetsmodel Ny Fremdrift. Ugeskrift for Loger, 166 (5), 404.

Kodate, N. (2010). Events, public discourses and responsive government: Quality assurance in health care in England, Sweden and Japan. Journal of Public Policy, 30 (3), 263289. doi:10.1017/S0143814X10000115

Krøll, V., \& Mainz, J. (2007). Danske Kvalitetsmodel - Set i Et Udviklingsperspektiv. Tidsskrift for Dansk Sundhedsvoesen, 10, 294-297.

Kuhlmann, S., \& Jäkel, T. (2013). Competing, collaborating or controlling? Comparing benchmarking in European local government. Public Money \& Management, 33 (4), 269-276. doi:10.1080/09540962.2013.799815

Larsson, B., Letell, M., \& Thörn, H. (Eds.). (2012). Transformations of the Swedish welfare state: From social engineering to governance? New York, NY: Palgrave Macmillan.

Levay, C., \& Waks, C. (2009). Professions and the pursuit of transparency in healthcare: Two cases of soft autonomy. Organization Studies, 30 (5), 509-527. doi:10.1177/ 0170840609104396

Lindgren, L., Ottosson, M., \& Salas, O. (2012). Öppna jämförelser: Ett styrmedel $i$ tiden eller "Hur kunde det bli så här?”. Göteborg, Sweden: FoU i Väst.

Mahoney, J., \& Thelen, K. (2010). Explaining institutional change: Ambiguity, agency, and power. Cambridge, UK: Cambridge University Press.

March, J. G., \& Olsen, J. P. (1989). Rediscovering institutions. New York, NY: The Free Press.

Moran, M. (2000). Understanding the welfare state: The case of health care. The British Journal of Politics and International Relations, 2, 135-160. doi:10.1111/ bjpi.2000.2.issue-2

NBHW. (2014). Nationella riktlinjer. Retrieved June 29, 2014, from http://www.socialstyrelsen.se/riktlinjer/ nationellariktlinjer

Nilsen, P. (Eds.). (2010). Implementering: Teori och tillämpning inom hälso- och sjukvård. Lund, Sweden: Studentlitteratur. 1.uppl. 
North, D. (1990). Institutions, institutional change and economic performance. Cambridge, UK: Cambridge University Press.

NPE. (2014). Nationell patientenkät. Retrieved June 28, 2014, from npe.skl.se

NQR. (2015). Nationella kvalitetsregister [National Quality Registries]. Retrieved March 24, 2015, from http://www. kvalitetsregister.se/sekundarnavigering/inenglish.4. f647a59141ef67b4342a3c.html

Öppna jämförelser. (2014). Öppna jämförelser av hälso- och sjukvårdens kvalitet och effektivitet: Jämförelser mellan landsting 2014 [Open comparisons]. Stockholm, Sweden: Socialstyrelsen.

Örnerheim, M., \& Wihlborg, E. (2014). Path dependence on new roads. Institutional development of quality registers. Scandinavian Journal of Public Administration, 18 (2), 3-22.

Ovretveit, J. (1994). A comparison of approaches to health service quality in the UK, USA \& Sweden and of the use of organizational audit frameworks. The European Journal of Public Health, 4 (1), 46-54. doi:10.1093/eurpub/4.1.46

Peterson, A., Carlhed, R., Lindahl, B., Lindström, G., Åberg, C., Andersson-Gäre, B., \& Bojestig, M. (2007). Improving guideline adherence through intensive quality improvement and the use of a national quality register in Sweden for acute myocardial infarction. Quality Management in Health Care, 16 (1), 25-37. doi:10.1097/00019514-200701000-00005

Pierson, P. (2000). Increasing returns, path dependence, and the study of politics. The American Political Science Review, 94 (2), 251-167. doi:10.2307/2586011

Pierson, P. (2004). Politics in time: History, institutions, and social analysis. Princeton, NJ: Princeton University Press.

Pierson, P. (2011, February). The welfare state in the very long run. ZeS-Working Paper. No. 2. University of Bremen, Bremen, Germany.

Pollitt, C., \& Bouckaert, G. (2011). Public management reform: A comparative analysis. New public management, governance, and the neo-Weberian state (3rd ed.). Oxford, UK: Oxford University Press.

Pressman, J. L., \& Wildavsky, A. (1973). Implementation. How great expectations in Washington are dashed in Oakland. Berkeley, CA: University of California Press.

Rådet for Medicinsk Kvalitetssikring. (1993). Kvalitetsstyringssystemer på danske sygehuse? - ISO 9000-serien. Ugeskrift for Loger, 155 (2), 124-126.

Right, K., \& Kjerulf, A/S. (2002). Erfaring og synspunkter på akkrediteringsforløbet i H:S, resultater af telefon- og gruppeinterview. Copenhagen: H:S Direktionen.

Right, K., \& Kjerulf, A/S. (2005). Erfaring og synspunkter på akkrediteringsforløbet i H:S, resultater af telefon- og gruppeinterview. Copenhagen: H:S Direktionen.

SALAR. (2010). Guldgruvan i hälso- och sjukvården: Förslag till gemensam satsning 2011-2015. Stockholm, Sweden: Sveriges kommuner och landsting [Swedish Association of Local Authorities and Regions].

Saltman, R. B., Vrangbaek, K., Lehto, J., \& Winblad, U. (2012). Consolidating national authority in Nordic health systems. Eurohealth, 18 (3), 21-24.

So ein Ding müssen wir auch haben. (1999). Ugeskrift for Loger, 161. 22 November.

Sønderjydske patienter får bedre kvalitet og sammenhæng, Ritzaus Bureau. (2001). 10 januar.

SOSFS. (1993). Kvalitetssäkring i hälso- och sjukvård inklusive tandvård, Socialstyrelsens föreskrifter. 9. Stockholm, Sweden.

SOSFS. (2011). Ledningssystem för systematiskt kvalitetsarbete, Socialstyrelsens föreskrifter och allmänna råd. 9. Stockholm, Sweden.

Sundhedsstyrelsen. (1993). National strategi for kvalitetsudvikling $i$ sundhedsvoesenet. København, Denmark: Sundhedsstyrelsen.

Sundhedsstyrelsen. (2000). Integrerbare kliniske databaser. delrapport: Status og resultater efter fase I. København, Denmark: Sundhedsstyrelsen. 